\title{
Emerging intravesical therapies for the management of bacillus Calmette-Guérin (BCG)-unresponsive non-muscle-invasive bladder cancer: Charting a path forward
}

\author{
Ali Cyrus Chehroudi; Peter Black \\ Department of Urologic Sciences, University of British Columbia, Vancouver, BC, Canada
}

Cite as: Can Urol Assoc J 2020 January 20; Epub ahead of print. http://dx.doi.org/10.5489/cuaj.6101

Published online January 20, 2020

$* * *$

\begin{abstract}
Management of patients with cacillus Calmette-Guérin (BCG)-unresponsive, high-risk, non-muscle-invasive bladder cancer (NMIBC) presents a formidable clinical challenge that requires urologists to weigh the competing risks of progression during further intravesical therapy vs. the morbidity of radical cystectomy. The prognosis of high-risk NMIBC recurring after BCG depends on the adequacy of prior BCG, the timing of recurrence, and tumor histology. The standard of care is currently radical cystectomy, as effective salvage intravesical therapy has not been established. The development of bladder-sparing treatments has been hampered to date by inconsistent definitions of BCG failure and difficulties in identifying appropriate control treatments in clinical trials. Despite these limitations, the spectrum of salvage therapy is expanding to include enhanced intravesical chemo-, gene, and immuno-therapies. In this review, we provide an overview of these emerging agents in the context of our current understanding of BCG failure and the unique considerations for clinical trial design in this disease state.
\end{abstract}




\section{Introduction}

Bladder cancer is the fifth most commonly diagnosed malignancy and is responsible for approximately 20,000 deaths per year in Canada and the United States. ${ }^{1,2,3}$ The majority $(\approx 75 \%)$ of tumours are non-muscle invasive. Standard therapies of non-muscle invasive bladder cancer (NMIBC) include transurethral bladder tumour resection (TURBT) and intravesical therapy with chemotherapy or Bacillus Calmette-Guérin (BCG). Despite optimal therapy, up to $80 \%$ of tumours recur, and anywhere from $0-40 \%$ progress to muscle-invasive disease, depending on risk factors. ${ }^{4}$ The treatment options especially for high grade NMIBC that has recurred despite optimal BCG therapy are limited. There are no established second-line salvage intravesical therapies, and the standard of care for these patients is radical cystectomy. The management of high grade NMIBC recurring on or after BCG therapy represents a critical unmet need in Urology. In this narrative review we aim to demonstrate the gaps in current standard management of NMIBC, and to review the novel therapies on the horizon to address these gaps.

\section{Optimal risk-adapted therapy for non-muscle-invasive bladder cancer}

NMIBC is stratified into low-, intermediate-, and high-risk disease states based on risk of recurrence and progression. The most important risk factors are T-stage, tumour grade, presence of carcinoma in situ (CIS), tumour size, multifocality, and prior history of recurrence (Table 1). ${ }^{5,6}$ Low and intermediate risk tumours are generally effectively managed with TURBT and judicious use of intravesical therapy. ${ }^{7}$ These may recur in a high proportion of cases $(40-60 \%)$. The risk of progression to higher stage disease is rare for low-risk disease, but ranges from $5-15 \%$ for intermediate risk disease. ${ }^{8}$ In contrast, high-risk patients are at increased risk of progression, measuring approximately $50 \%$ over 15 years in one series. ${ }^{4,9}$ Standard of care for high-risk disease is intravesical immunotherapy with BCG. BCG is believed to augment the anti-tumour immune response by promoting T-cell recruitment, cytotoxic activity, and cytokine release. ${ }^{10} \mathrm{~A}$ Cochrane review on intermediate- and high-risk NMIBC demonstrated that BCG reduced the odds of disease progression by $56 \%$ compared to TURBT alone. ${ }^{11}$ BCG has also been shown to be superior to mitomycin $\mathrm{C}(\mathrm{MMC})$ in reducing recurrence (OR 0.56) $)^{12}$. The direct comparison to MMC with respect to progression is less clear ${ }^{13,14}$, but only BCG with maintenance has been shown to reduce progression in an individual trial ${ }^{15}$. Optimal BCG is delivered as a weekly induction for 6 weeks followed by 3 weekly maintenance instillations at 3, 6, 12, 18, 24, 30 and 36 months, as per prior randomized controlled trials (RCTs) which demonstrate superior oncological outcomes this maintenance protocol. $^{15,16}$ 


\section{Defining recurrence after $\mathrm{BCG}$}

Unfortunately, BCG will fail in 30-40\% of patients with NMIBC. ${ }^{17}$ High-grade recurrence after $\mathrm{BCG}$ presents a challenging scenario and the evidence for optimal treatment of these patients is difficult to interpret because of varied definitions of BCG failure. Technically, a BCG failure can be taken to represent any recurrence during or after BCG therapy. However, several factors help to stratify BCG failure, including the timing of recurrence and the adequacy of prior BCG. BCG failure is often stratified into BCG-relapsing, -refractory, and -unresponsive disease, assuming adequate BCG induction and maintenance ${ }^{18}$ (Figure 1). BCG relapsing disease can be heterogenous depending on the time to relapse. An early relapse has a similar outcome to BCG refractory disease, but late relapses may respond to additional $\mathrm{BCG}^{19}$ and generally have a more favorable outcome. ${ }^{20,21}$ An early relapse is defined as recurrence within 6 months of the last BCG dose for papillary (Ta/T1) NMIBC and within 12 months for CIS. ${ }^{21}$ BCG-refractory NMIBC is defined as high-grade recurrence or failure to eradicate disease with induction and the first cycle of maintenance BCG (or second induction cycle) if the recurrence is CIS or high grade Ta disease. If the recurrence is a high grade T1 tumour, it is considered BCG-refractory after induction BCG alone. Any patient with BCG-refractory NMIBC or an early relapse is termed to be BCG-unresponsive. This is an important definition for both clinical practice and clinical trial design, as it delineates a group of patients who are unlikely to benefit from additional BCG.

The natural history of BCG refractory disease is often progression to muscle-invasive cancer, metastasis, and even death. ${ }^{9,22}$ It is essential to re-evaluate the upper tract and prostatic urethra in patients with suspected recurrence after BCG since approximately $50 \%$ of patients will harbour disease in these locations. ${ }^{23}$ Historical data suggest that the risk of metastasis in patients with $\mathrm{BCG}$ failure reaches $50 \%$ after 3 additional cycles of BCG. ${ }^{24}$ Complete response rates to a second course of BCG range from $20 \%-50 \%$ depending on the category of BCG failure, tumour histology, and presence of CIS, which is associated with $50 \%$ progression. ${ }^{26}$ Early radical cystectomy provides the best oncologic outcomes with a disease-free rate greater than $90 \% .{ }^{27}$ All forms of salvage intravesical therapy for both BCG refractory and relapsing disease must be considered oncologically inferior to cystectomy. ${ }^{6}$

Salvage intravesical therapy in North America often consists of BCG/interferon-alpha (BCG/IFN). The evidence in support of this regimen comes from a large prospective trial of over $400 \mathrm{BCG}$ naïve and failure patients (including both refractory and relapsing disease), which showed cancer-free rates at 2 years of $59 \%$ and $45 \%$, respectively, when treated with BCG/IFN. ${ }^{28}$ A subsequent re-analysis showed that response to BCG/IFN was strongly associated with the category of BCG failure ${ }^{29}$. To illustrate, BCG refractory 
patients had only $34 \%$ recurrence-free survival compared to $53 \%$ for patients relapsing within 12-24 months. The largest limitation is that there is no data directly comparing $\mathrm{BCG} / \mathrm{IFN}$ to BCG monotherapy, which is regarded as an appropriate therapy in the late BCG-relapsing disease space.

\section{Emerging chemotherapeutic agents}

The use of intravesical chemotherapeutic agents such as gemcitabine, valrubicin, epirubicin and docetaxel as salvage therapy for BCG failure has been under investigation for at least 20 years (Table 2). Of these, only valrubicin is currently Food and Drug Administration (FDA) approved for management of BCG-refractory CIS based on a phase 2 multicentre single-arm trial which demonstrated a $21 \%$ complete-response rate in patients with recurrent CIS. ${ }^{30}$ This translated to an $8 \%$ disease-free rate at 30 months, which would likely be inadequate for FDA approval currently. While it is the only FDA approved drug in this setting, and although there are currently no other established standard salvage therapies for BCG-unresponsive disease, valrubicin is not necessarily most commonly used. Intravesical gemcitabine represents a reasonable option based on trial data and its known efficacy when administered systemically for muscle invasive and metastatic urothelial carcinoma. Gemcitabine was shown to be superior to MMC in a head-to-head RCT for BCG failure. ${ }^{31}$ Another RCT comparing repeat BCG to intravesical gemcitabine showed that the latter significantly improved recurrence-free survival (19\% vs. $3 \%$ ), although it did not impact disease progression. ${ }^{32}$ Barlow and colleagues treated 54 NMIBC (87\% high-risk) BCG non-responders with intravesical docetaxel induction and maintenance with a $25 \%$ recurrence-free survival at 3 years and $85 \%$ disease-specific survival at 5 years. ${ }^{33}$ Combination therapy has also been tested with encouraging results. ${ }^{34}$

A key short-coming in these trials is that they were conducted prior to our current understanding of optimal BCG, the importance of maintenance BCG, and risk-stratifying BCG failures. These considerations were also not reflected in older NMIBC guidelines. ${ }^{35}$ Therefore, the inclusion criteria for these studies did not control for the dose/duration of $\mathrm{BCG}$ and time from completion of BCG to recurrence. BCG intolerant patients were also commonly combined with refractory/relapsing patients, and some studies included intermediate risk patients. Lastly, since these are mostly single-arm efficacy trials without a control group we cannot conclude whether the above treatments are superior to repeat BCG. Despite these limitations, there is little disagreement within the urologic community that the outcomes of salvage intravesical chemotherapy in patients recurring after BCG are sub-optimal. We can cautiously conclude that approximately $70-80 \%$ will have a recurrence within 2 years after starting salvage chemotherapy. 


\section{Clinical trial design and BCG failure}

Given the limited utility of salvage intravesical chemotherapy in the management of BCG failure, there is a large unmet need for novel bladder-sparing therapies. Indeed, since 1959 there have only been 2 new treatments approved by the FDA (valrubicin and thiotepa), neither of which has demonstrated robust anti-tumour response. Much of the limited development in NMIBC therapeutics stems from ethical and logistical questions that form the backbone of designing meaningful clinical trials for BCG failure:

1. How do we define BCG failure when recruiting patients for clinical trials?

2. How do we appropriately combine patients who have CIS vs. high-grade papillary recurrence on BCG?

3. What is the most appropriate control group when comparing a novel therapy (e.g. cystectomy vs. repeat BCG vs. investigator's choice salvage therapy)?

4. Is it safe to delay cystectomy in operative candidates to evaluate a novel intravesical therapy?

5. What is the most clinically relevant outcome when weighing competing comorbidities in the NMIBC population (e.g. overall survival, disease-specific survival, response rates, recurrence)?

The FDA held a special meeting in 2013 in conjunction with representatives from the American Urological Association to discuss these implications and to improve consensus on clinical trial design in BCG failure. ${ }^{36}$ This collaboration triggered the subsequent evolution of the term "BCG-unresponsive",37, 38 and finally a guidance document from the FDA for conducting clinical trials in this disease space. ${ }^{39}$ A key objective of these initiatives was to define stringent inclusion criteria for clinical trials that would eliminate some of the patient heterogeneity encountered in prior studies.

Contributing to the heterogeneity of the NMIBC population are the differences in natural history and management of CIS compared to papillary tumours ( $\mathrm{Ta} / \mathrm{T} 1)$. Patients with CIS are presumed to have residual disease at the time of starting intravesical therapy, while patients with papillary tumours have undergone complete resection of their disease. Disease eradication with novel therapies can therefore only be demonstrated in patients with CIS. As a result, the FDA typically requires that the primary endpoint of registration trials in the $\mathrm{BCG}$-unresponsive disease state be the complete response (CR) rate in patients with CIS (with or without concomitant papillary tumour). Patients with papillary tumors only are still included in the trials, and high-grade recurrence-free survival of these patients usually constitutes a co-primary or secondary endpoint of the trial. The FDA has suggested that an investigational agent should demonstrate a $\mathrm{CR}$ rate of $40-50 \%$ at 6 months for BCG-refractory CIS and a recurrence free-survival rate for $\mathrm{Tis} / \mathrm{Ta} / \mathrm{T} 1$ tumors of $30 \%$ at $18-24$ months with the lower limit of the $95 \%$ confidence 
interval excluding 20\%. These numbers have been criticized for being unrealistic and some worry it will further deter drug development in an already challenging disease state. ${ }^{40}$ It remains to be seen if the FDA will approve a novel therapy for both CIS and $\mathrm{Ta} / \mathrm{T} 1$ patients based on this type of trial design, as the final approval decision will always be dependent on panel review of clinical trial results for the individual agent.

The FDA accepts single arm phase 2 trials for registration of novel therapies in patients with BCG-unresponsive NMIBC because there is consensus in the field that there is no appropriate control group to which to compare. ${ }^{39}$ A placebo or further BCG would be considered unethical. One could consider randomization to radical cystectomy, but the feasibility of such a trial would be low. If a new agent is approved in the near future, standard clinical trial design could evolve to include randomization to the newly approved agent.

Another important question is whether cystectomy can be safely delayed to evaluate a novel therapy. Retrospective studies have shown that cystectomy can be delayed up to 1 year after initial TURBT in high-risk BCG-refractory urothelial carcinoma with no effect on disease-specific mortality. ${ }^{41}$ Furthermore, prospective studies following the natural history of BCG treatment demonstrated that progression rarely occurs at 6 months and the median time to progression of T1HG disease is approximately 24 months. ${ }^{42}$ Furthermore, the recently presented preliminary data from the Keynote 057 trial showed that none of 102 patients with BCG-unresponsive CIS progressed during a median of 15.8 months of follow-up. ${ }^{43}$

\section{Novel therapies}

Therapies currently being investigated for BCG failure are summarized in Table 3, with certain examples highlighted in the text below.

\section{Enhanced intravesical chemotherapy}

Device-assisted chemotherapy aims to improve the penetration of the drug through the urothelium using heat (chemohyperthermia; CHT) or electrical current (electromotive drug administration). Of the two, chemohyperthermia has been studied more extensively in the setting of BCG failure. ${ }^{44,45,46}$ The Synergo system (radiofrequency-induced thermochemotherapy (RITE)) uses a catheter with microwave applicator at the tip that heats $\mathrm{MMC}$ in the bladder to $41-44^{\circ} \mathrm{C}$. Data on CHT are largely heterogeneous with recurrence-free survival ranging from $25-50 \% .{ }^{44}$ Arends and colleagues ${ }^{47}$ collected prospective data on high- and intermediate-risk NMIBC ( $81 \%$ had prior BCG) treated with MMC or epirubicin with CHT and report a 2-year recurrence-free survival of approximately 50\% for both agents. The recently reported HYMN trial randomized 104 intermediate or high risk patients after BCG failure to either RITE or "institutional 
standard second-line therapy" (i.e. electromotive mitomycin, repeat BCG, or conventional mitomycin). ${ }^{48}$ There was no difference in disease-free survival or 3 month CR rate in CIS patients. This trial, however, has been criticized for design concerns, especially the heterogeneity of the patient population, and the details of drug delivery, especially the dose of mitomycin delivered. ${ }^{49}$ Van Valenberg and colleagues retrospectively examined the outcomes of patients with CIS +/- papillary NMIBC receiving Synergo. ${ }^{50}$ Amongst patients with a complete response at 6 months, recurrencefree rates were $17 \%$ for BCG-unresponsive and $27.3 \%$ in other categories of BCG failure. However, only half of patients with BCG-unresponsive disease and $70 \%$ of other failures were able to achieve CR.

Another early concept is the use of standard intravesical chemotherapy agents incorporated into micelles. These nanoparticles are believed to act as mucoadhesives, improving the attachment of cytotoxic agents to the urothelium, increasing dwell time, and enhancing drug uptake. ${ }^{51}$ A single-arm phase 2 trial testing albumin-bound paclitaxel in 28 high-risk NMIBC patients with recurrence after BCG induction (i.e. not true BCGunresponsive NMIBNC) demonstrated recurrence-free survival of $18 \%$ and cancerspecific survival of $91 \%$ at a median follow-up of 41 months. ${ }^{52}$ It is not clear that these results are any better than would be anticipated with un-encapsulated docetaxel. A clinical trial investigating intravesical hyperconjugated polyglycerol-encapulsated docetaxel is under way. ${ }^{53}$

\section{Photodynamic therapy}

Photodynamic therapy uses light energy to eradicate malignant urothelial cells. Systems currently being investigated first require intravesical instillation of a photosensitizing agent followed by insertion of a urinary catheter capable of transmitting light from an external source. Bader et al. ${ }^{54}$ tested photodynamic therapy with hexaminolevulinate in a small series of 17 patients with recurrent NMIBC. While the majority had high-grade disease, only 12 had prior BCG therapy with no data on adequacy or nature of recurrence. Twelve percent of patients were tumour-free at 21 months. A Phase I study investigating a different photosensitizer (TLD1433) has been completed ${ }^{49}$ and a larger phase II trial in the BCG-unresponsive setting is planned. ${ }^{50}$

\section{Immunotherapy}

Inhibitors of programmed cell death protein (PD1) and PD1 ligand (PDL1), (collectively termed immune checkpoint inhibitors) represent a major breakthrough in the treatment of patients with metastatic bladder cancer. These agents interrupt a negative regulatory signal that suppresses tumor cell kill by activated T-cells, thereby triggering an antitumour response. ${ }^{57,58}$ Two registration trials are testing the efficacy of checkpoint 
inhibitors in BCG-unresponsive NMIBC. ${ }^{43,59}$ Keynote 057 reported preliminary results at the annual meeting of the European Society of Medical Oncology in October 2018. The 3-month CR rate in 102 patients with BCG-unresponsive CIS was 40.2\%. ${ }^{43}$ These therapies would represent a potential paradigm change for the management of patients with NMIBC since they are systemic therapies usually administered by medical oncologists in North America.

\section{Gene therapy}

Gene therapy is one of the most active areas of translational research for bladder cancer, and three promising agents are in advanced stages of clinical development.

Adstiladrin $\AA$ (rebranded from Instiladrin $\AA$; nadofaragene firadenovec) is a replication-deficient adenovirus programmed to express interferon-alpha, that is administered together with an incipient Syn3 to promote update of the virus into tumour tissue. This agent has passed through phase I and II trials and is now being tested in a second large single arm trial (phase III). Of 40 patients with BCG-unresponsive NMIBC in the phase II trial, 14 (35\%) were free of high grade recurrence at 12 months. ${ }^{60}$ The phase III trial is an FDA registration trial. ${ }^{61}$

CG007 is a conditionally replicating oncolytic adenovirus that expresses granulocytemonocyte colony stimulating factor (GM-CSF). Viral replication and GM-CSF expression are directly and indirectly under the control of the E2F-1 promoter, ${ }^{62}$ which is active only in cancer cells with loss of retinoblastoma $(\mathrm{Rb})$. This provides tumor selectivity. After a successful phase I study that demonstrated safety and an early signal for efficacy, ${ }^{63} \mathrm{CG} 0070$ was tested in a single arm phase II trial in patients with BCGunresponsive NMIBC. ${ }^{64}$ The agent was administered weekly for a 6 week induction course, followed by maintenance dosing at 6,12 , and 18 months. Interim results from 45 patients revealed a $47 \% \mathrm{CR}$ rate at 6 months. In a subsequent update ${ }^{65}$ of these trial results in a meeting presentation, the CR rate at 12 months in 61 patients was $30 \%(27 \%$ in CIS and 38\% in pure Ta/T1). Ten patients underwent cystectomy, of whom 6 had MIBC. Most of the adverse events related to lower urinary tract symptoms, in addition to flu-like symptoms and fatigue. Final results of this trial will determine if it can move towards FDA approval and clinical implementation.

BC-819 is a plasmid administered intravesically with polyethyleneimine, a cationic membrane permeabilizer. ${ }^{66}$ The plasmid encodes the diphtheria toxin under the control of the H19 promoter sequence, an oncofetal transcription factor upregulated in urothelial carcinoma. Selective synthesis of diphtheria toxin in tumour cells causes arrest of protein synthesis and subsequent cell death without compromising the benign urothelium. A phase 2 marker lesion trial was completed in $2013^{67}$ for patients with intermediate-risk disease only (no high grade or CIS) who had recurrent or persistent disease after at least 1 
course of any intravesical therapy. The authors report that BC-819 eradicated one-third of all marker lesions and $40 \%$ of patients remained disease-free at 2 years. A trial testing BC-819 in BCG-unresponsive NMIBC has not yet launched. ${ }^{68}$

\section{Targeted therapy}

Vicinium (oportuzumap monatox; VB4-845) is a recombinant protein comprised of a single chain variable fragment of a humanized anti-EpCAM antibody fused to Pseudomonas exotoxin A. ${ }^{69}$ Its tumour specificity rests on increased plasma membrane expression of the EpCAM surface marker on urothelial carcinoma. ${ }^{70}$ Binding of the antiEpCAM component to EpCAM causes internalization of the Pseudomonas exotoxin by receptor-mediated endocytosis, and the toxin causes arrest of protein synthesis. Vicinium is therefore only efficacious against tumours expressing EpCAM, which has been a consistent inclusion criterium for enrolment in clinical trials.

In a phase 2 study with EpCAM-expressing CIS, most of which was BCG refractory, $40 \%$ of patients obtained a CR and $16 \%$ remained disease-free at 18-25 month followup $^{71}$. Interim results from a single arm phase III FDA registration trial in patients with BCG-unresponsive NMIBC were reported at the 2018 meeting of the AUA. ${ }^{72}$ Vicinium was instilled into the bladder two times per week for 6 weeks followed by weekly for 6 weeks and every 2 weeks for up to 2 years. The CR rate at 3 months in CIS patients was $42 \%$. The 12 month results of this trial are expected in mid 2019. There is also a phase III trial testing Vicinum in combination with the checkpoint inhibitor durvalumab (NCT03258593). ${ }^{73}$

\section{Conclusions}

The landscape of clinical trials in BCG failure has shifted dramatically from intravesical chemotherapy to novel gene, immune, and targeted therapies with more consistent standards for patient selection and outcome reporting. Most studies remain single-arm trials due to the lack of a defined control to which to compare. Since the BCGunresponsive patient population is still quite heterogenous, it is impossible to compare drugs across trials. Encouraging early results have been reported for several agents, including especially Vicinium, Adstiladrin ${ }^{\circledR}$, GC0070 and Pembrolizumab, so that any one or more of these agents could obtain FDA approval in the US in the near future. Once one or more agent is available in clinical practice, the clinical trial space will need to evolve to encompass comparison trials to the newly established effective agents. If multiple agents are approved, we will need to investigate whether there are markers to guide the use of one therapy over another, and to guide the best sequence of therapies. Combination therapies will be an important future area of clinical trial investigation. 
Furthermore, it remains to be seen how systemic delivery of a checkpoint inhibitor will be accepted in this patient population, especially if intravesical alternatives are available.

It is important to bear in mind that these therapies are being tested in patients who are ineligible for or decline cystectomy for BCG-unresponsive NMIBC. Many patients ultimately chose clinical trial participation over cystectomy, and some proceed to cystectomy if the trial agent does not work. With one or more effective, FDA-approved salvage therapy options for patients with BCG-unresponsive NMIBC it will be even more important to identify in which patients it is safe to delay cystectomy. 


\section{References}

1. Kassouf W, et al. CUA guidelines on management of non-muscle invasive bladder cancer. Can Urol Assoc J 2015;9(9-10): E690-704.

2. Cancer.ca. Toronto: Canadian Cancer Society; c2019 [updated 2019]. https://www.cancer.ca/en/cancer-information/cancertype/bladder/statistics/?region=on. Accessed July 20, 2019.

3. Siegel RL, Miller KD, Jemal A. Cancer Statistics, 2018. CA Cancer J Clin 2018;68(1):7-30.

4. Sylvester RJ, van der Meijden AP, Oosterlinck W, et al. Predicting recurrence and progression in individual patients with stage Ta T1 bladder cancer using EORTC risk tables: a combined analysis of 2596 patients from seven EORTC trials. Eur Urol 2006;49(3):466-77.

5. Chang SS, Boorjian SA, Chou R, et al. Diagnosis and Treatment of Non-Muscle Invasive Bladder Cancer: AUA/SUO Guideline. J Urol 2016;196(4):1021-9

6. Babjuk M, Böhle A, Burger M, et al. EAU Guidelines of Non-muscle-invasive Urothelial Carcinoma of the Bladder: Update 2016. Eur Urol 2017; 71(3):447-61.

7. Kamat AM, Witjes JA, Brausi M, et al. Defining and treating the spectrum of intermediate risk non-muscle invasive bladder cancer. J Urol 2014; 192: 305-15.

8. Matsumoto K, Kikuchi E, Yanai Y, et al. Characterizing intermediate-risk nonmuscle-invasive bladder cancer: Implications for the definition of intermediate risk and treatment strategy. Urol Oncol 2017;35(5):208-214.

9. Cookson MS, Herr HW, Zhang ZF, et al. The treated natural history of high risk superficial bladder cancer: 15 year outcome. J Urol 1997;158:62-7.

10. Patard JJ, Chopin DK, Boccon-Gibod L. Mechanisms of action of bacillus CalmetteGuérin in the treatment of superficial bladder cancer. World J Urol 1993;11(3):165-8.

11. Shelley MD, Kynaston H, Court J, Wilt TJ, Coles B, Burgon K, Mason MD. A systematic review of intravesical bacillus Calmette-Guérin plus transurethral resection vs transurethral resection alone in Ta and T1 bladder cancer. BJU Int 2001;88(3):209-16.

12. Bohle A, Jocham D, Bock PR. Intravesical bacillus Calmette-Guerin versus mitomycin $\mathrm{C}$ for superficial bladder cancer: a formal meta-analysis of comparative studies on recurrence and toxicity. J Urol 2003;169:90-5.

13. Malmström PU, Sylvester RJ, Crawford DE, et al. An individual patient data metaanalysis of the long-term outcome of randomised studies comparing intravesical mitomycin $\mathrm{C}$ versus bacillus Calmette-Guérin for non-muscle-invasive bladder cancer. Eur Urol 2009;56(2):247-56.

14. Bohle A, Bock PR. Intravesical bacille Calmette-Guerin versus mitomycin $\mathrm{C}$ in superficial bladder cancer: formal meta-analysis of comparative studies on tumor progression. Urology 2004;63:682-6.

15. Lamm DL, et al. Maintenance BCG immunotherapy for recurrent Ta, T1 and CIS transitional cell carcinoma of the bladder: a randomized SWOG study. J Urol 2000;163: 1124-9. 
16. Oddens J, Brausi M, Sylvester R, et al. Final results of an EORTC-GU cancers group randomized study of maintenance bacillus Calmette-Guerin in intermediate- and high-risk Ta, T1 papillary carcinoma of the urinary bladder: One-third dose versus full dose and 1 year versus 3 years of maintenance. Eur Urol 2013;63:462-72.

17. Witjes JA. Management of BCG failures in superficial bladder cancer: a review. Eur Urol 2006;49:790-7.

18. Shirakawa H, Kikuchi E, Tanaka N, et al. Prognostic significance of Bacillus Calmette-Guérin failure classification in non-muscle-invasive bladder cancer. BJU Int 2012;110(6 Pt B):E216-21.

19. Bretton PR, Herr HW, Kimmel M, et al. The response of patients with superficial bladder cancer to a second course of intravesical bacillus Calmette-Guerin. J Urol 1990;143(4):710-2.

20. Herr HW, Milan TN, Dalbagni G. BCG-refractory vs. BCG-relapsing non-muscleinvasive bladder cancer: a prospective cohort outcomes study. Urol Oncol 2015;33(3):108.e1-4.

21. Steinberg RL, Thomas LJ, Mott SL, O’Donnell MA. Bacillus Calmette-Guérin (BCG) treatment failures with non-muscle invasive bladder cancer: a data-driven definition for BCG unresponsive disease. Bladder Cancer 2016; 27(2): 215-24.

22. Lerner SP, Tangen CM, Sucharew H, et al. Failure to achieve a complete response to induction BCG therapy is associated with increased risk of disease worsening and death in patients with high risk non-muscle invasive bladder cancer. Urol Oncol 2009;27(2):155-9.

23. Giannarini G, Birkhäuser FD, Recker F, et al. Bacillus Calmette-Guérin failure in patients with non-muscle-invasive urothelial carcinoma of the bladder may be due to the urologist's failure to detect urothelial carcinoma of the upper urinary tract and urethra. Eur Urol 2014 Apr;65(4):825-31.

24. Catalona WJ, Hudson MA, Gillen DP, et al. Risks and benefits of repeated courses of intravesical bacillus Calmette-Guerin therapy for superficial bladder cancer. $J$ Urol 1987;137(2):220-4.

25. O'Donnell MA, Boehle A. Treatment options for BCG failures. World J Urol 2006;24(5):481-7.

26. Coplen DE, Marcus MD, Myers JA, et al. Long-term followup of patients treated with 1 or 2, 6-week courses of intravesical bacillus Calmette-Guerin: analysis of possible predictors of response free of tumor. J Urol 1990;144(3):652-7.

27. Haas CR, Barlow LJ, Badalato GM, et al. The Timing of Radical Cystectomy for bacillus Calmette-Guérin Failure: Comparison of Outcomes and Risk Factors for Prognosis. J Urol 2016;195(6):1704-9.

28. Joudi FN, Smith BJ, O'Donnell MA, et al. Final results from a national multicenter phase II trial of combination bacillus Calmette-Guérin plus interferon alpha-2B for reducing recurrence of superficial bladder cancer. Urol Oncol 2006; 24(4):344-8.

29. Gallagher BL, Joudi FN, Maymí JL, et al. Impact of previous bacille Calmette-Guérin failure pattern on subsequent response to bacille Calmette-Guérin plus interferon intravesical therapy. Urology 2008;71(2):297-301. 
30. Steinberg G, Bahnson R, Brosman S, et al. Efficacy and safety of valrubicin for the treatment of Bacillus Calmette-Guerin refractory carcinoma in situ of the bladder. The Valrubicin Study Group. J Urol 2000;163(3):761-7.

31. Addeo R, Caraglia M, Bellini S et al. Randomized phase III trial on gemcitabine versus mytomicin in recurrent superficial bladder cancer: evaluation of efficacy and tolerance. J Clin Oncol 2010; 28(4): 543-8.

32. Di Lorenzo G, Perdonà S, Damiano R, et al. Gemcitabine versus bacille CalmetteGuérin after initial bacille Calmette-Guérin failure in non-muscle-invasive bladder cancer: a multicenter prospective randomized trial. Cancer 2010;116(8):1893-900.

33. Barlow LJ, McKiernan JM, Benson MC. Long-term survival outcomes with intravesical docetaxel for recurrent nonmuscle invasive bladder cancer after previous bacillus Calmette-Guérin therapy. J Urol 2013;189(3):834-9.

34. Steinberg RL, Thomas LJ, O’Donnell MA. Combination Intravesical Chemotherapy for Non-muscle-invasive Bladder Cancer. Eur Urol Focus 2018; 4(4):503-5.

35. Babjuk M, Oosterlinck W, Sylvester R, et al. EAU guidelines on non-muscle-invasive urothelial carcinoma of the bladder. Eur Urol 2008;54(2):303-14.

36. Jarow JP, Lerner SP, Kluetz PG, et al. Clinical trial design for the development of new therapies for nonmuscle-invasive bladder cancer: report of a Food and Drug Administration and American Urological Association public workshop. Urology 2014;83(2):262-4.

37. Jarrow J, Mahler VE, Ibrahim A, et al. Development of systemic and topical drugs to treat non-muscle invasive bladder cancer. Bladder Cancer 2015;1(2): 133-6.

38. Lerner SP, Dinney C, Kamat A, et al. Clarification of bladder cancer disease states following treatment of patients with intravesical BCG. Bladder Cancer 2015;1:29-30.

39. Food and Drug Administration. BCG-Unresponsive Nonmuscle Invasive Bladder Cancer: Developing Drugs and Biologics for Treatment Guidance for Industry. Feb 2018. Available from https://www.fda.gov/ucm/groups/fdagov-public/@fdagovdrugs-gen/documents/document/ucm529600.pdf.

40. Amrhein J, Kamat AM, Morales A. Re: Jarow JP et al.: Clinical trial design for the development of new therapies for non-muscle-invasive bladder cancer: report of a Food and Drug Administration and American Urological Association public workshop (Urology 2014;83:262-265). Urology 2014 Aug;84(2):494-5.

41. Jäger W, Thomas C, Haag S, et al. Early vs delayed radical cystectomy for 'high-risk' carcinoma not invading bladder muscle: delay of cystectomy reduces cancer-specific survival. BJU Int 2011;108(8 Pt 2):E284-8.

42. Millán-Rodríguez F, Chéchile-Toniolo G, Salvador-Bayarri J, et al. Primary superficial bladder cancer risk groups according to progression, mortality and recurrence. J Urol 2000;164(3 Pt 1):680-4.

43. Balar AV, Kulkarni GS, Uchio E, et al. Keynote 057: Phase II trial of Pembrolizumab (pembro) for patients (pts) with high-risk (HR) nonmuscle invasive bladder cancer (NMIBC) unresponsive to bacillus calmette-guérin (BCG). J Clin Oncol 2019; 37(suppl_7): 350 . 
44. Lammers RJ, Witjes JA, Inman BA, et al. The role of a combined regimen with intravesical chemotherapy and hyperthermia in the management of non-muscleinvasive bladder cancer: a systematic review. Eur Urol 2011;60(1):81-93.

45. Di Stasi SM, Giannantoni A, Giurioli A, et al. Sequential BCG and electromotive mitomycin versus BCG alone for high-risk superficial bladder cancer: a randomized controlled trial. Lancet Oncol 2006; 7(1):43-51.

46. Racioppi M, Di Gianfrancesco L, Ragonese M, et al. ElectroMotive drug administration (EMDA) of Mitomycin $\mathrm{C}$ as first-line salvage therapy in high risk "BCG failure" non muscle invasive bladder cancer: 3 years follow-up outcomes. BMC Cancer 2018; 18:1224.

47. Arends TJ, van der Heijden AG, Witjes JA, et al. Combined chemohyperthermia: 10year single center experience in 160 patients with nonmuscle invasive bladder cancer. J Urol 2014;192(3):708-13.

48. Tan WS, Panchal A, Buckley L, et al. Radiofrequency-induced thermo-chemotherapy effect versus a second course of Bacillus Calmette-Guérin or institutional standard in patients with recurrence of non-muscle invasive bladder cancer following induction or maintenance Bacillus-Calmette Guérin therapy (HYMN): a phase III, open-label, randomized controlled trial. Eur Urol 2019; 75(1):63-71.

49. Witjes JA. Radiofrequency-induced thermochemotherapy for recurrent non-muscle invasive bladder cancer: a new treatment for an unmet need? Eur Urol 2019; 75(1):72-3.

50. Van Valengerg FJP, Kajtazovic A, Canepa G, et al. Intravesical RadiofrequencyInduced Chemohyperthermia for Carcinoma in Situ of the Urinary Bladder: A Retrospective Multicentre Study. Bladder Cancer 2018;4(4):365-376.

51. Mugabe C, Hadaschik BA, Kainthan RK, et al. Paclitaxel incorporated in hydrophobically derivatized hyperbranched polyglycerols for intravesical bladder cancer therapy. BJU Int 2009;103(7):978-86.

52. Robins DJ, Sui W, Matulay JT, et al. Long-term Survival Outcomes With Intravesical Nanoparticle Albumin-bound Paclitaxel for Recurrent Non-muscle-invasive Bladder Cancer After Previous Bacillus Calmette-Guérin Therapy. Urology 2017;103:149-53.

53. Clinicaltrials.gov. Bethesda: US National Library of Medicine; c2016 [updated April $18,2018]$.

https:/clinicaltrials.gov/ct2/show/NCT02982395?term=docetaxel\&recrs=a\&cond=b1 adder+cancer\&rank=1. Accessed April 15, 2019.

54. Bader MJ, Stepp H, Beyer W, et al. Photodynamic Therapy of Bladder Cancer - A Phase I Study Using Hexaminolevulinate (HAL). Urol Oncol 2013;31(7):1178-83.

55. Clinicaltrials.gov. Bethesda: US National Library of Medicine; c2017 [updated August 20, 2018]. https://clinicaltrials.gov/ct2/show/NCT03053635. Accessed April $15,2019$.

56. Clinicaltrials.gov. Bethesda: US National Library of Medicine; c2019 [updated May 10, 2019]. https://clinicaltrials.gov/ct2/show/NCT03945162. Accessed July 20, 2019.

57. Bellmunt J, de Wit R, Vaughn DJ, et al. Pembrolizumab as Second-Line Therapy for Advanced Urothelial Carcinoma. N Engl J Med 2017;376(11):1015-26. 
58. Balar AV, Castellano D, O'Donnell PH, et al. Pembrolizumab as first-line therapy in cisplatin-ineligible advanced urothelial cancer: Results from the total KEYNOTE-052 study population. Presented at ASCO-GU 2017; abstract \#284.

59. Clinicaltrials.gov. Bethesda: US National Library of Medicine; c2016 [updated May 27, 2019]. https://clinicaltrials.gov/ct2/show/study/NCT02844816?show locs=Y\#locn. Accessed May 28, 2019.

60. Shore ND, Boorjian SA, Canter DJ, et al. Intravesical rAd-IFN $\alpha / S y n 3$ for Patients With High-Grade, Bacillus Calmette-Guerin-Refractory or Relapsed Non-MuscleInvasive Bladder Cancer: A Phase II Randomized Study. J Clin Oncol 2017; 35(30): 3410-6.

61. Clinicaltrials.gov. Bethesda: US National Library of Medicine; c2016 [updated May 24, 2018]. https://clinicaltrials.gov/ct2/show/NCT02773849. Accessed May 15, 2019.

62. Ramesh N, Ge Y, Ennist DL, et al. CG0070, a conditionally replicating granulocyte macrophage colony-stimulating factor--armed oncolytic adenovirus for the treatment of bladder cancer. Clin Cancer Res 2006;12(1):305-13.

63. Burke JM, Lamm DL, Meng MV, et al. A first in human phase 1 study of CG0070, a GM-CSF expressing oncolytic adenovirus, for the treatment of nonmuscle invasive bladder cancer. J Urol 2012;188(6):2391-7.

64. Packiam VT, Lamm DL, Barocas DA, et al. An open label, single-arm, phase II multicenter study of the safety and efficacy of CG0070 oncolytic vector regimen in patients with BCG-unresponsive non-muscle-invasive bladder cancer: Interim results. Urol Oncol 2018; 36(10):440-7.

65. Packiam VT, Barocas DA, Chamie K, et al. LBA24 CG0070, An Oncolytics Adenovirus, for BCG-unresposnive non-muscle invasive bladder cancer (NMIBC): 12 month interim results from a multicenter phase II trial. J Urol 2018; 199(4S):e1166.

66. Amit D, Hochberg A. Development of targeted therapy for bladder cancer mediated by a double promoter plasmid expressing diphtheria toxin under the control of H19 and IGF2-P4 regulatory sequences. J Transl Med 2010;8:134.

67. Gofrit ON, Benjamin S, Halachmi S, et al. DNA based therapy with diphtheria toxinA BC-819: a phase $2 \mathrm{~b}$ marker lesion trial in patients with intermediate risk nonmuscle invasive bladder cancer. J Urol 2014;191(6):1697-702.

68. Clinicaltrials.gov. Bethesda: US National Library of Medicine; c2018 [updated May 3, 2019]. https://clinicaltrials.gov/ct2/show/NCT03719300. Accessed May 15, 2019.

69. Biggers K, Scheinfeld N. VB4-845, a conjugated recombinant antibody and immunotoxin for head and neck cancer and bladder cancer. Curr Opin Mol Ther 2008;10(2):176-86.

70. Brunner A, Prelog M, Verdorfer I, et al. EpCAM is predominantly expressed in high grade and advanced stage urothelial carcinoma of the bladder. $J$ Clin Pathol 2008;61(3):307-10. 
71. Kowalski M, Guindon J, Brazas L, et al. A phase II study of oportuzumab monatox: an immunotoxin therapy for patients with noninvasive urothelial carcinoma in situ previously treated with bacillus Calmette-Guérin. J Urol 2012;188(5):1712-8.

72. Dickstein R, Wu N, Cowan B, et al. LBA27 phase 3 study of Vicinium in BCGunresponsive non-muscle invasive bladder cancer: initial results. J Urol 2018 199(4s):e1167.

73. Clinicaltrials.gov. Bethesda: US National Library of Medicine; c2017 [updated May 9, 2019]. https://clinicaltrials.gov/ct2/show/NCT03258593. Accessed May 15, 2019.

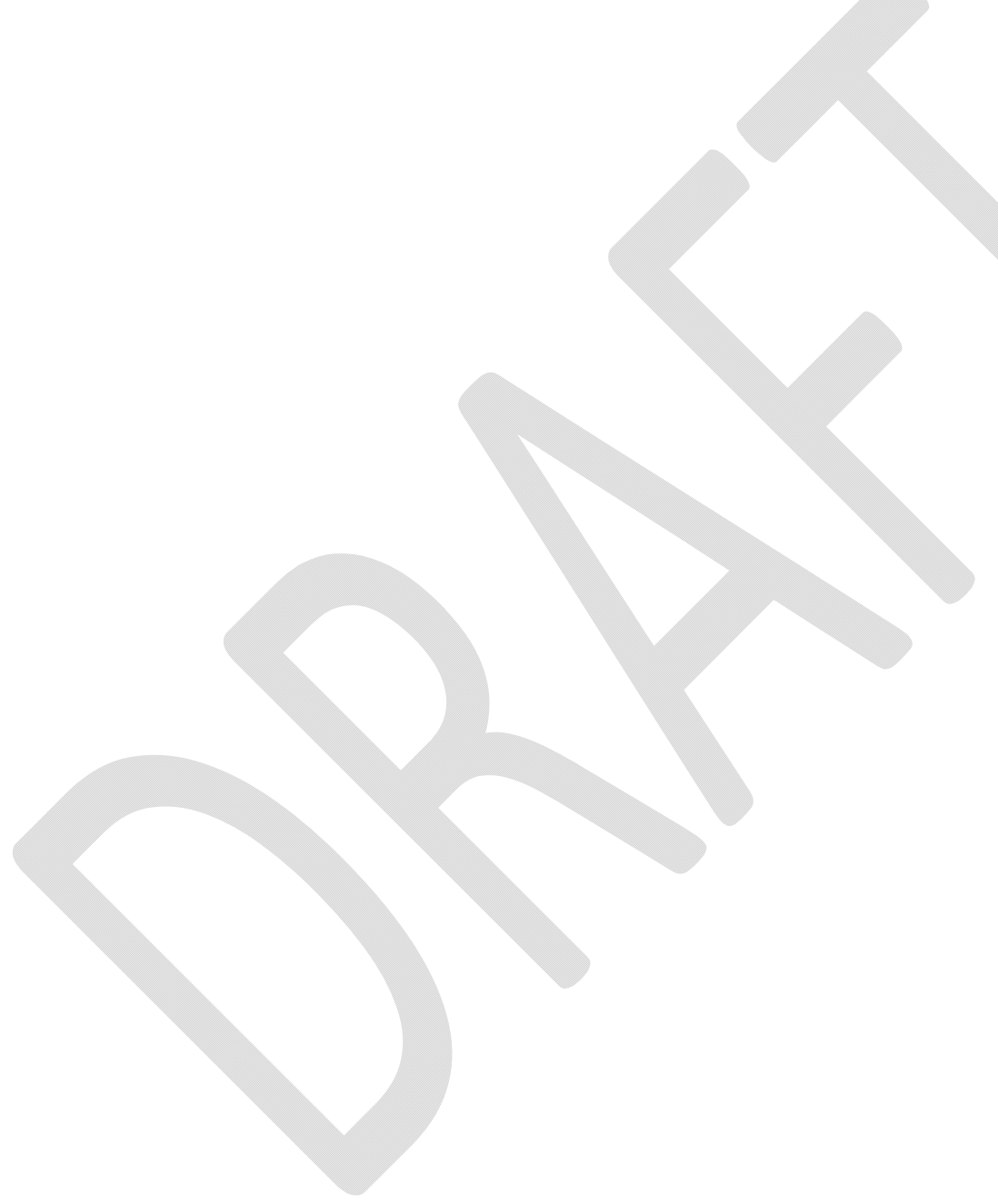




\section{Figures and Tables}

Fig. 1. Overview of standard of care for bladder cancer. *All evaluations should comprise of cystoscopy, urine cytology, and random bladder biopsies for CIS. Papillary disease at 3 months requires resection. Any recurrence while on BCG with muscleinvasive disease is managed according to the MIBC pathway. BCG bacillus Calmette Guerin; CIS: carcinoma in situ; MIBC: muscle invasive bladder cancer; NMIBC: non-muscle-invasive bladder cancer.

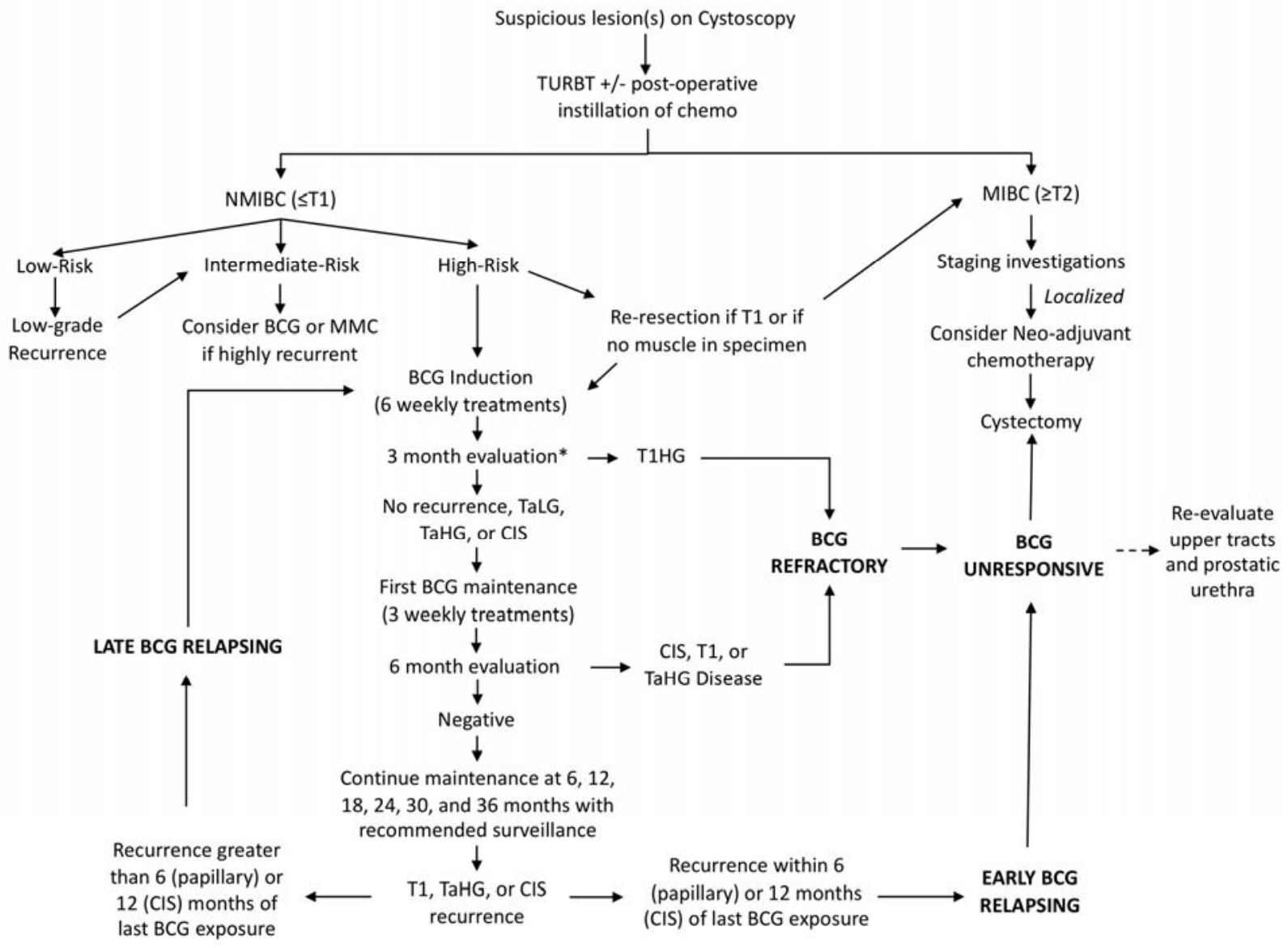




\begin{tabular}{|l|l|l|}
\hline \multicolumn{3}{|l|}{ Table 1. Risk stratification for NMIBC (2016 AUA guidelines) } \\
\hline Low-risk & Intermediate-risk & High-risk \\
\hline $\begin{array}{l}\text { Low-grade solitary Ta } \leq 3 \\
\text { cm }\end{array}$ & $\begin{array}{l}\text { Recurrence with 1-year } \\
\text { low-grade Ta }\end{array}$ & High-grade T1 \\
\hline $\begin{array}{l}\text { Papillary neoplasm of low } \\
\text { malignant potential }\end{array}$ & $\begin{array}{l}\text { Solitary low-grade Ta }>3 \\
\text { cm }\end{array}$ & $\begin{array}{l}\text { Any recurrent, high-grade } \\
\text { Ta }\end{array}$ \\
\hline & Low-grade Ta, multifocal & $\begin{array}{l}\text { High-grade Ta, }>3 \mathrm{~cm} \text { (or } \\
\text { multifocal) }\end{array}$ \\
\hline & High-grade Ta, $\leq 3 \mathrm{~cm}^{*}$ & Any CIS \\
\hline & Low-grade $\mathrm{T1}{ }^{*}$ & $\begin{array}{l}\text { Any BCG failure in high- } \\
\text { grade case }\end{array}$ \\
\hline & & Any variant histology \\
\hline & & Any LVI \\
\hline & & $\begin{array}{l}\text { Any high-grade prostatic } \\
\text { urethral involvement }\end{array}$ \\
\hline
\end{tabular}

${ }^{*}$ EUA and CUA guidelines for non-muscle-invasive bladder cancer classify these tumors has high-risk. The downgrading of these tumors to intermediate-risk by the AUA was based on the lack of BCG maintenance in studies assessing progression and how the panel felt these tumors would behave with adequate BCG. AUA: American Urological Association; BCG bacillus Calmette Guerin; CIS: carcinoma in situ; CUA: Canadian Urological Association; EAU: European Association of Urology; LVI: lymphovascular invasion; NMIBC: non-muscle-invasive bladder cancer. 


\begin{tabular}{|c|c|c|c|c|}
\hline Agent & Study & Study design & Inclusion criteria & Outcome \\
\hline Valrubicin & $\begin{array}{l}\text { Steinberg et } \\
\mathrm{al}^{1}\end{array}$ & $\begin{array}{l}\text { Phase } 2 \text {, } \\
\text { single-arm trial }\end{array}$ & $\begin{array}{l}\text { 1. Any failure or } \\
\text { recurrence after } \\
6 \text {-week } \\
\text { induction BCG } \\
\text { for CIS } \\
\text { 2. BCG intolerant }\end{array}$ & $\begin{aligned} &- 20 \% \text { complete } \\
& \text { response } \\
&- 8 \% \text { disease- } \\
& \text { free at } 30 \\
& \text { months } \\
&- 50 \% \text { required } \\
& \text { cystectomy }\end{aligned}$ \\
\hline Gemcitabine & Adeo et $\mathrm{al}^{2}$ & $\begin{array}{l}\text { RCT of } \\
\text { intravesical } \\
\text { gemcitabine } \\
\text { vs. MMC }\end{array}$ & $\begin{array}{l}\text { 1. Any recurrence } \\
\text { or progression } \\
\text { after BCG of } \\
\text { unspecified } \\
\text { dose/duration. } \\
\text { 2. BCG ineligible } \\
\text { patients }\end{array}$ & $\begin{array}{l}-72 \% \text { of } \\
\text { gemcitabine } \\
\text { and } 61 \% \text { of } \\
\text { MMC patients } \\
\text { free of disease } \\
\text { at median of } \\
36 \text { months } \\
\end{array}$ \\
\hline Gemcitabine & $\begin{array}{l}\text { Dalbagni et } \\
\mathrm{al}^{3}\end{array}$ & $\begin{array}{l}\text { Phase } 2, \\
\text { single-arm trial }\end{array}$ & $\begin{array}{l}\text { 1. Disease that } \\
\text { was deemed } \\
\text { refractory to } \\
\text { BCG of } \\
\text { unspecified } \\
\text { dose/duration } \\
\text { 2. BCG } \\
\text { intolerance }\end{array}$ & $\begin{array}{l}-39 \% \text { complete } \\
\text { response } \\
-21 \% \text { disease- } \\
\text { free at } 1 \text { year }\end{array}$ \\
\hline Gemcitabine & 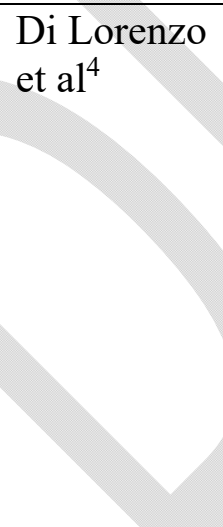 & $\begin{array}{l}\text { RCT of } \\
\text { intravesical } \\
\text { gemcitabine } \\
\text { vs. repeat BCG }\end{array}$ & $\begin{array}{l}\text { 1. Patients failing } \\
\text { BCG as per } \\
\text { EAU } 2008 \\
\text { guidelines (do } \\
\text { not account for } \\
\text { dose/duration of } \\
\text { BCG or BCG } \\
\text { refractory vs. } \\
\text { relapsing } \\
\text { disease) }\end{array}$ & $\begin{array}{l}-19 \% \text { of } \\
\text { gemcitabine } \\
\text { and } 3 \% \text { of } \\
\text { repeat BCG } \\
\text { patient free of } \\
\text { disease at } 2 \\
\text { years } \\
-\quad 35 \% \\
\text { progression } \\
\text { for both } \\
\text { groups }\end{array}$ \\
\hline
\end{tabular}

${ }^{1}$ Steinberg G, Bahnson R, Brosman S, et al. Efficacy and safety of valrubicin for the treatment of Bacillus Calmette-Guerin refractory carcinoma in situ of the bladder. The Valrubicin Study Group. J Urol 2000;163:761-7. ${ }^{2}$ Adeo R, Caraglia M, Bellini S, et al. Randomized, phase 3 trial on gemcitabine vs. mytomicin in recurrent superficial bladder cancer: Evaluation of efficacy and tolerance. $J$ Clin Oncol 2010;28:543-8. ${ }^{3}$ Dalbagni G, Russo P, Ben-Porat L, et al. Phase 2 trial of intravesical gemcitabine in bacille CalmetteGuérin-refractory transitional cell carcinoma of the bladder. J Clin Oncol 2006;24:272934. ${ }^{4}$ Di Lorenzo G, Perdonà S, Damiano R, et al. Gemcitabine vs. bacille Calmette- 
Guérin after initial bacille Calmette-Guérin failure in non-muscle-invasive bladder cancer: A multicenter, prospective, randomized trial. Cancer 2010:116:1893-900. BCG bacillus Calmette Guerin; CIS: carcinoma in situ; EAU: European Association of Urology; LVI: lymphovascular invasion; MMC: mitomycin C; NMIBC: non-muscleinvasive bladder cancer; RCT: randomized control trial.

\begin{tabular}{|c|c|c|c|c|c|}
\hline Agent & Study & Study design & Inclusion criteria & Mechanism & $\begin{array}{l}\text { Primary } \\
\text { outcomes }\end{array}$ \\
\hline \multicolumn{6}{|c|}{ Enhanced intravesical chemotherapies } \\
\hline Synergo & $\begin{array}{l}\text { NCT024 } \\
71495\end{array}$ & $\begin{array}{l}\text { Phase } 3, \\
\text { single-arm trial }\end{array}$ & $\begin{array}{l}\text { Persistent CIS after } \\
\text { induction plus } \\
\text { maintenance BCG } \\
\text { at } 6 \text { months, } \\
\text { recurrent disease } \\
\text { within } 3 \text { months of } \\
\text { starting BCG, or } \\
\text { disease progression }\end{array}$ & $\begin{array}{l}\text { Microwave- } \\
\text { emitting catheter to } \\
\text { improve penetrance } \\
\text { of MMC }\end{array}$ & $\begin{array}{l}\text { Recurrence-free } \\
\text { survival }\end{array}$ \\
\hline Nanoxel & $\begin{array}{l}\text { NCT029 } \\
82395 \\
{[47]}\end{array}$ & $\begin{array}{l}\text { Phase 3, } \\
\text { double-arm, } \\
\text { open-label } \\
\text { study } \\
\text { comparing } \\
\text { nanoxel to } \\
\text { mitomycin C }\end{array}$ & $\begin{array}{l}\text { Any NMIBC } \\
\text { "unresponsive" to } \\
\text { BCG }\end{array}$ & $\begin{array}{l}\text { Paclitaxel- } \\
\text { containing micelles } \\
\text { (nanoparticles) }\end{array}$ & $\begin{array}{l}\text { Recurrence-free } \\
\text { survival }\end{array}$ \\
\hline $\begin{array}{l}\text { Nab-Rapamycin } \\
\text { (ABI-009) }\end{array}$ & $\begin{array}{l}\text { NCT020 } \\
09332\end{array}$ & $\begin{array}{l}\text { Combined } \\
\text { phase } 1 \text { and } 2, \\
\text { single-arm } \\
\text { study }\end{array}$ & $\begin{array}{l}\text { Phase } 2 \text { : high-grade } \\
\text { NMIBC BCG } \\
\text { refractory }{ }^{1} \text { or } \\
\text { relapsing }<6 \\
\text { months despite } \\
\text { adequate BCG }\end{array}$ & $\begin{array}{l}\text { Rapamycin- } \\
\text { containing micelles } \\
\text { (nanoparticles) }\end{array}$ & Adverse events \\
\hline $\begin{array}{l}\text { Intravesical } \\
\text { Cabazitaxel, } \\
\text { Gemcitabine, } \\
\text { and Cisplatin }\end{array}$ & $\begin{array}{l}\text { NCT022 } \\
02772\end{array}$ & $\begin{array}{l}\text { Phase 1, } \\
\text { single-arm }\end{array}$ & $\begin{array}{l}\text { High-grade NMIBC } \\
\text { with persistent or } \\
\text { recurrent disease } \\
\text { after BCG } \\
\text { induction }\end{array}$ & $\begin{array}{l}\text { Combination } \\
\text { intravesical } \\
\text { chemotherapy }\end{array}$ & $\begin{array}{l}\text { Safety and } \\
\text { tolerability }\end{array}$ \\
\hline
\end{tabular}




\begin{tabular}{|c|c|c|c|c|c|}
\hline $\begin{array}{l}\text { Photodynamic } \\
\text { therapy }\end{array}$ & $\begin{array}{l}\text { NCT030 } \\
53635\end{array}$ & $\begin{array}{l}\text { Phase 1, } \\
\text { single-arm }\end{array}$ & $\begin{array}{l}\text { Any NMIBC with } \\
\text { persistent tumor } \\
\text { after adequate BCG } \\
\text { or BCG intolerant }\end{array}$ & $\begin{array}{l}\text { Instillation of } \\
\text { photosensitizer } \\
\text { (TLD1433) } \\
\text { followed by } \\
\text { transurethral } \\
\text { irrradiation }\end{array}$ & $\begin{array}{l}\text { Safety and } \\
\text { tolerability }\end{array}$ \\
\hline \multicolumn{6}{|l|}{ Immunotherapy } \\
\hline \multirow[t]{2}{*}{ Durvalumab } & $\begin{array}{l}\text { NCT033 } \\
17158\end{array}$ & $\begin{array}{l}\text { Multi-arm, } \\
\text { phase } 1 / 2 \\
\text { study } \\
\text { comparing } \\
\text { durvalumab } \pm \\
\text { BCG } \pm \text { EBRT }\end{array}$ & $\begin{array}{l}\text { Any-grade recurrent } \\
\text { NMIBC despite } \\
\text { adequate BCG }\end{array}$ & \multirow[t]{4}{*}{$\begin{array}{l}\text { PD-1 inhibitor, } \\
\text { enhancing T-cell } \\
\text { mediated anti-tumor } \\
\text { activity }\end{array}$} & $\begin{array}{l}\text { Phase 1: } \\
\text { Determine } \\
\text { recommended } \\
\text { combination doses } \\
\text { Phase 2: 6-month } \\
\text { relapse-free } \\
\text { survival (RFS) }\end{array}$ \\
\hline & $\begin{array}{l}\text { NCT029 } \\
01548\end{array}$ & $\begin{array}{l}\text { Phase } 2, \\
\text { single-arm, } \\
\text { open-label }\end{array}$ & $\begin{array}{l}\text { BCG refractory or } \\
\text { relapsing }<9 \\
\text { months CIS only }\end{array}$ & & CR rate \\
\hline \multirow[t]{2}{*}{ Pembrolizumab } & $\begin{array}{l}\text { NCT028 } \\
08143\end{array}$ & $\begin{array}{l}\text { Phase 1, dose- } \\
\text { escalation }\end{array}$ & $\begin{array}{l}\text { High-grade NMIBC } \\
\text { BCG refractory or } \\
\text { relapsing }<6 \\
\text { months despite } \\
\text { adequate } \mathrm{BCG} \text {. }\end{array}$ & & $\begin{array}{l}\text { Maximum } \\
\text { tolerated dose of } \\
\text { pembrolizumab }\end{array}$ \\
\hline & $\begin{array}{l}\text { NCT026 } \\
25961\end{array}$ & $\begin{array}{l}\text { Phase 2, } \\
\text { single-arm, } \\
\text { open-label }\end{array}$ & $\begin{array}{l}\text { High-risk NMIBC } \\
\text { unresponsive to } \\
\text { adequate BCG } \\
\text { (undefined) }\end{array}$ & & $\begin{array}{l}\mathrm{CR} \text { rate } \\
\text { Disease-free } \\
\text { survival rate }\end{array}$ \\
\hline \multirow[t]{2}{*}{ Atezolizumab } & $\begin{array}{l}\text { NCT028 } \\
44816 \\
{[50]}\end{array}$ & $\begin{array}{l}\text { Phase 2, } \\
\text { single-arm, } \\
\text { open-label }\end{array}$ & $\begin{array}{l}\text { High-grade NMIBC } \\
\text { BCG refractory or } \\
\text { relapsing }<6 \\
\text { months }\end{array}$ & \multirow[t]{2}{*}{$\begin{array}{l}\text { PD-L1 inhibitor, } \\
\text { enhancing T-cell } \\
\text { mediated anti- } \\
\text { tumour activity }\end{array}$} & $\begin{array}{l}\text { CR rate } \\
\text { Event-free } \\
\text { survival }\end{array}$ \\
\hline & $\begin{array}{l}\text { NCT027 } \\
92192\end{array}$ & $\begin{array}{l}\text { Phase } 2 \text {, multi- } \\
\text { arm trial } \\
\text { comparing } \\
\text { atezolizumab } \pm \\
\text { BCG stratified } \\
\text { by BCG- } \\
\text { unresponsive }\end{array}$ & $\begin{array}{l}\text { Any BCG- } \\
\text { refractory or - } \\
\text { relapsing NMIBC } \\
\text { with CIS }\end{array}$ & & $\begin{array}{l}\text { Adverse events } \\
\text { Maximum } \\
\text { tolerated dose of } \\
\text { BCG in } \\
\text { combination with } \\
\text { atezolizumab } \\
\text { CR rate }\end{array}$ \\
\hline
\end{tabular}




\begin{tabular}{|c|c|c|c|c|c|}
\hline & & $\begin{array}{l}\text { and relapsing } \\
\text { disease }\end{array}$ & & & \\
\hline ALT-801 & $\begin{array}{l}\text { NCT016 } \\
25260\end{array}$ & $\begin{array}{l}\text { Phase } 1 \mathrm{~b} / 2 \text {, } \\
\text { single-arm trial } \\
\text { of combination } \\
\text { intravenous } \\
\text { ALT- } 801 \text { and } \\
\text { intravesical } \\
\text { gemcitabine }\end{array}$ & $\begin{array}{l}\text { Any high-grade } \\
\text { NMIBC, multi- } \\
\text { focal disease, or } \\
\text { tumour }>4 \mathrm{~cm} \text {. } \\
\text { BCG intolerant or } \\
\text { recurrent disease } \\
\text { after } 1 \text { course of } \\
\text { BCG }\end{array}$ & $\begin{array}{l}\text { Recombinant IL-2- } \\
\text { T-cell receptor } \\
\text { domain fusion } \\
\text { protein. Potent IL-2 } \\
\text { receptor agonist }\end{array}$ & $\begin{array}{l}\text { Adverse events } \\
\text { CR rate }\end{array}$ \\
\hline $\begin{array}{l}\text { PANVAC } \\
\text { Vaccine }\end{array}$ & $\begin{array}{l}\text { NCT020 } \\
15104\end{array}$ & $\begin{array}{l}\text { Phase 2, RCT } \\
\text { of BCG alone } \\
\text { vs. BCG + } \\
\text { PANVAC }\end{array}$ & $\begin{array}{l}\text { Any high-grade } \\
\text { NMIBC recurring } \\
\text { after at least } 1 \\
\text { induction course of } \\
\text { BCG }\end{array}$ & $\begin{array}{l}\text { Subcutaneous } \\
\text { vaccine composed } \\
\text { of viral vectors } \\
\text { encoding common } \\
\text { tumor antigens }\end{array}$ & $\begin{array}{l}\text { Improved disease- } \\
\text { free survival in } \\
\text { PANVAC + BCG } \\
\text { group }\end{array}$ \\
\hline \multicolumn{6}{|c|}{ Recombinant intravesical therapies } \\
\hline \multirow[t]{2}{*}{ rAd-IFN $\alpha /$ Syn3 } & \begin{tabular}{|l} 
NCT016 \\
87244
\end{tabular} & $\begin{array}{l}\text { Phase } 2, \mathrm{RCT} \\
\text { comparing } 2 \\
\text { doses }\end{array}$ & $\begin{array}{l}\text { High-grade BCG } \\
\text { relapsing or } \\
\text { refractory NMIBC }\end{array}$ & \multirow[t]{2}{*}{$\begin{array}{l}\text { Interferon- } \alpha \\
\text { expressing } \\
\text { adenovirus }\end{array}$} & $\begin{array}{l}35 \% \text { of patients } \\
\text { free of high-grade } \\
\text { disease at } 12 \\
\text { months }\end{array}$ \\
\hline & \begin{tabular}{|l|} 
NCT027 \\
73849
\end{tabular} & $\begin{array}{l}\text { Phase } 3 \text {, } \\
\text { single-arm, } \\
\text { open label }\end{array}$ & $\begin{array}{l}\text { High-grade NMIBC } \\
\text { BCG relapsing }<12 \\
\text { months }\end{array}$ & & $\begin{array}{l}\text { CR rate in patients } \\
\text { with CIS }\end{array}$ \\
\hline \multirow[t]{2}{*}{ Vicinium } & $\begin{array}{l}\text { Kowalsk } \\
\text { i et al }{ }^{65}\end{array}$ & $\begin{array}{l}\text { Phase } 2 \text {, non- } \\
\text { randomized, } \\
\text { open-label trial } \\
\text { comparing 6- } \\
\text { vs. 12-week } \\
\text { induction }\end{array}$ & $\begin{array}{l}\text { High-grade NMIBC } \\
\text { failing to respond to } \\
\geq 1 \text { cycle of } B C G \text { or } \\
\text { BCG-intolerant }\end{array}$ & \multirow[t]{2}{*}{$\begin{array}{l}\text { Pseudomonas } \\
\text { exotoxin-anti- } \\
\text { EpCAM fusion } \\
\text { protein }\end{array}$} & $\begin{array}{l}\sim 40 \% \text { CR in both } \\
\text { groups at } 3 \\
\text { months }\end{array}$ \\
\hline & \begin{tabular}{|l|} 
NCT024 \\
49239
\end{tabular} & $\begin{array}{l}\text { Phase 3, } \\
\text { single-arm }\end{array}$ & $\begin{array}{l}\text { High-grade NMIBC } \\
\text { with any } \\
\text { recurrence/persisten } \\
\text { ce despite adequate } \\
\text { BCG }\end{array}$ & & CR rate \\
\hline $\begin{array}{l}\text { CG0070 } \\
\text { oncolytic virus }\end{array}$ & \begin{tabular}{|l|} 
NCT023 \\
65818
\end{tabular} & $\begin{array}{l}\text { Phase } 2, \\
\text { single-arm trial }\end{array}$ & $\begin{array}{l}\text { Any high-grade } \\
\text { NMIBC that is } \\
\text { BCG refractory or }\end{array}$ & $\begin{array}{l}\text { GMCSF-expressing } \\
\text { oncolytic virus }\end{array}$ & $\begin{array}{l}\% \text { with } \mathrm{CR}>12 \\
\text { months }\end{array}$ \\
\hline
\end{tabular}




\begin{tabular}{|c|c|c|c|c|c|}
\hline & & & $\begin{array}{l}\text { relapsing up to } 24 \\
\text { months from last } \\
\text { BCG exposure }\end{array}$ & & \\
\hline \multicolumn{6}{|c|}{ Other therapies } \\
\hline Sunitinib & $\begin{array}{l}\text { NCT011 } \\
18351\end{array}$ & $\begin{array}{l}\text { Phase } 2, \\
\text { single-arm } \\
\text { open label }\end{array}$ & $\begin{array}{l}\text { Any recurrent } \\
\text { NMIBC following } \\
\text { BCG treatment }\end{array}$ & $\begin{array}{l}\text { Tyrosine kinase } \\
\text { inhibitor }\end{array}$ & CR rate \\
\hline $\begin{array}{l}\text { Vicinium }+ \\
\text { Durvalumab }\end{array}$ & $\begin{array}{l}\text { NCT032 } \\
58593\end{array}$ & $\begin{array}{l}\text { Phase 1, } \\
\text { single-arm }\end{array}$ & $\begin{array}{l}\text { High-grade NMIBC } \\
\text { BCG refractory or } \\
\text { relapsin }\end{array}$ & See above & $\begin{array}{l}\text { Safety and } \\
\text { tolerability }\end{array}$ \\
\hline
\end{tabular}

${ }^{1}$ The concepts BCG refractory, BCG relapsing, and adequate BCG are consistent with the definitions outlined in the text. BCG bacillus Calmette Guerin; CIS: carcinoma in situ; CR: complete response; MMC: mitomycin C; NMIBC: non-muscle-invasive bladder cancer; RCT: randomized control trial. 